DOI: $10.2478 /$ achi-2020-0013

\title{
PHYSICAL PROPERTIES OF OIL-RICH SLUDGE-CLAY MIXED BRICKS
}

\author{
Nur Najibah Ahmad Kamil ${ }^{\text {a }}$, Agus Arsad ${ }^{\text {a }}$, Muhamad Abbas \\ Ahmad Zaini $^{\text {b* }}$ \\ ${ }^{a}$ Institute for Oil and Gas (IFOG), Universiti Teknologi Malaysia, 81310 \\ UTM Johor Bahru, Johor, Malaysia \\ ${ }^{b}$ Centre of Lipids Engineering and Applied Research (CLEAR), Ibnu-Sina \\ Institute for Scientific and Industrial Research, Universiti Teknologi \\ Malaysia, 81310 UTM Johor Bahru, Johor, Malaysia
}

\begin{abstract}
Oil-rich sludge (ORS) is a by-product of oleochemical industry. The present study was aimed to investigate the influence of sludge on the mechanical and durability properties of clay brick. Eight partial replacements of $5 \%, 10 \%$, $15 \%, 20 \%, 25 \%, 30 \%, 35 \%$ and $40 \%$ of sludge types in clay formulation were evaluated. Eight hundred bricks with uniform size of $50 \mathrm{~mm} \times 50 \mathrm{~mm} \times 50 \mathrm{~mm}$ were hand-molded, burnt in a furnace at $900{ }^{\circ} \mathrm{C}$, and were subjected to water absorption test and compressive test. The result shows that the water absorption of sludge blended bricks increased with increasing amount of sludge. The water absorption percentage is between $29 \%$ and $69 \%$. The compressive strength of bricks is ranging between $0.85 \mathrm{~N} / \mathrm{mm}^{2}$ and $13.26 \mathrm{~N} / \mathrm{mm}^{2}$, whereby wet and dry sludge revealed a greater compressive strength of more than $5 \mathrm{~N} / \mathrm{mm}^{2}$ for partial replacements up to $20 \%$. Clay with $20 \%$ and less blend of ORS shows good quality of brick. Brick formulated with ORS could be beneficial for the construction economy and environment.
\end{abstract}

Keywords: Oil-rich sludge, Clay brick, Environment, Partial replacement, Physical properties

\footnotetext{
* Muhammad Abbas Ahmad Zaini, e-mail: abbas@cheme.utm.my
} 


\section{Introduction}

Due to rapid urbanization and economic growth, developing countries worldwide are facing an increasing development in manufacturing industries. This has resulted in an increasing amount of wastes being generated and stored - often ended-up at landfill. Landfilling has been the most economical waste disposal option in the country, where more than $95 \%$ of wastes received is disposed in landfills. ${ }^{1}$ Generally, sewage sludge is mainly produced from domestic and light industrial activities. In Malaysia for example, about 3 million metric tons of sewage sludge is generated annually, and it has been estimated to rise at 7 million metric tons in year $2020 .^{2}$ Therefore, there is an urgency to quest for the best possible way to reduce the dependence on landfill as the sole waste disposal approach.

Sludge is a residue of wastewater treatment from industries such as chemical manufacturing, metal fabrication, rubber product, metal finishing and electroplating. ${ }^{3,4}$ Oil-rich sludge (ORS) is a wastewater treatment residue in soap manufacturing process. The sludge cake is oily, rich in moisture content (ca. $50 \%$ ), white in color and has a pungent odor. It also endows a high amount of calcium which brings about the propensity to be applied as building material, specifically brick.

The utilization of sludge as construction material is not a completely new field of study. Few researchers reported some interesting outcomes from the usage of several types of sludge, such as paper industry, tannery sludge, iron or arsenic sludge and sludge ash as building blocks since early $2000 .^{4,5}$ Yousif and co-workers ${ }^{6}$ from Egypt employed sludge from water treatment facility in making cylindrical brick with water absorption ranging from $15 \%$ to $22 \%$, and compressive strength between $24.5 \mathrm{MPa}$ and 37.8 MPa. Similarly, Kadir and co-workers ${ }^{7}$ formulated a brick from zinc- 
containing sludge with water absorption of $21 \%$ and compressive strength of 23.0 MPa. Eliche-Quesada et al. ${ }^{8,9}$ studied the properties of green clay bricks with different amounts of waste materials such as sawdust, spent earth, compost and sludge from oil refinery. They concluded that a $10 \%$ partial replacement, except for sawdust (5\%) allows sufficient compressive strength for structural application. Jewaratnam ${ }^{4}$ reported an increase in compressive strength of brick with increasing amount of sludge rich in calcium, iron, and aluminum from electroplating industry. Undoubtedly, the exploitation of sludge in valuable commodity such as brick material contributes to the sustainable environment.

However, the properties of bricks by partial replacement of oil-rich sludge are not well documented in literature. To the best of our knowledge, there is no report that describes the use of this kind of sludge in brick manufacturing. Therefore, the present work was embarked at evaluating the physical properties of oil-rich sludge-clay mixed bricks for potential applications in building and construction industries. Four types of sludge, namely dry, wet, oil-free and ash, all derived from the parent material were employed as partial replacement in clay brick. The raw material was characterized, and the findings were analyzed and discussed.

\section{Experimental}

\section{Oil-rich sludge and clay}

The oil-rich sludge (ORS) was obtained from a wastewater treatment facility in soap manufacturing factory in Pasir Gudang, Johor state of Malaysia. The material was further processed and classified into four replacement materials, i.e., wet, dry, oil-free and ash. The processing procedures are summarized in Table 1. 
Table 1. Oil-rich sludge processing.

\begin{tabular}{ll}
\hline ORS derivative & Method of processing \\
\hline Wet & Raw oil-rich sludge (as-is) \\
Dry & $\begin{array}{l}\text { Air-dried for } 7 \mathrm{~d} \text {, and oven-dried at } 80{ }^{\circ} \mathrm{C} \\
\text { for } 24 \mathrm{~h}\end{array}$ \\
Oil-free & $\begin{array}{l}\text { Air-dried for } 7 \mathrm{~d} \text {, and oven-dried at } 200 \\
{ }^{\circ} \mathrm{C} \text { for } 8 \mathrm{~h}\end{array}$ \\
Ash & Pyrolysis in a furnace at $900{ }^{\circ} \mathrm{C}$ for $8 \mathrm{~h}$ \\
\hline
\end{tabular}

Clay is a main ingredient in brick formulation. It is a natural soil that contains hydrous aluminium phyllosilicates $\left(\mathrm{Al}_{2} \mathrm{O}_{3} \cdot 2 \mathrm{SiO}_{2} \cdot 2 \mathrm{H}_{2} \mathrm{O}\right)$. Alumina develops plasticity when wet and acts as a cementing material in brick, while silica prevents brick from cracking and shrinking. In this work, clay was collected at Pontian, Johor state of Malaysia. The sample was air-dried for $7 \mathrm{~d}$, ground and sieved using a wire mesh to a size of about $1 \mathrm{~mm}$.

\section{Sludge characterization and analysis}

The ORS was characterized for proximate analysis and ash content using furnace at $850{ }^{\circ} \mathrm{C}$ for $2.5 \mathrm{~h}$. The elemental analysis was performed using a Macro Cube Elementar. The surface composition of ORS and ash was estimated using an EDX machine. The oil content of ORS was obtained by Soxhlet extraction using n-hexane.

\section{Brick making process and testing}

ORS was blended with clay at different formulations of $5 \%, 10 \%$, $15 \%, 20 \%, 25 \%, 30 \%, 35 \%$ and $40 \%$ by weight to produce mixtures of $51: 19,1: 9,3: 17,1: 4,1: 13,3: 7,7: 13$ and 2:3, respectively (Table 2). Water was added into the mixture of ORS and clay, and the mixing was performed on impermeable surface. The brick material was spread into a reasonably large surface to obtain a homogeneous mixture with uniform color. The 
brick was hand-molded to a uniform size of $50 \mathrm{~mm} \times 50 \mathrm{~mm} \times 50 \mathrm{~mm}$. The dimension of the test brick is smaller than the standard size due to the space limitations inside muffle furnace. A total of 800 bricks of different types and replacement ratios were prepared and analyzed.

Table 2. Formulation of sludge in clay brick.

\begin{tabular}{cccc}
\hline $\begin{array}{c}\text { Mixture } \\
\text { identification }\end{array}$ & $\begin{array}{c}\text { Mass ratio } \\
\text { of ORS }\end{array}$ & $\begin{array}{c}\text { Mass ratio } \\
\text { of clay }\end{array}$ & $\begin{array}{c}\text { Amount } \\
\text { of water } \\
(\%)\end{array}$ \\
\hline ORS brick 5\% & 1 & 19 & 30 \\
ORS brick 10 \% & 1 & 9 & 30 \\
ORS brick 15 \% & 3 & 17 & 30 \\
ORS brick 20 \% & 1 & 4 & 30 \\
ORS brick 25 \% & 1 & 3 & 30 \\
ORS brick 30 \% & 3 & 7 & 30 \\
ORS brick 35 \% & 7 & 13 & 30 \\
ORS brick 40 \% & 2 & 3 & 30 \\
\hline
\end{tabular}

The bricks were air-dried for $7 \mathrm{~d}$, followed by slow heating at $80{ }^{\circ} \mathrm{C}$ for $8 \mathrm{~h}$, and $150{ }^{\circ} \mathrm{C}$ for another $8 \mathrm{~h}$. Next, the bricks were subjected to a firing process at $900{ }^{\circ} \mathrm{C}$ for $10 \mathrm{~h}$. The low heating rate of $4{ }^{\circ} \mathrm{C} / \mathrm{min}$ is necessary to remove excessive moisture, and to avoid cracks due to alphabeta quartz phase transition. ${ }^{10}$ Then, the bricks were allowed to cool inside a furnace chamber overnight prior to performance evaluation. The compressive strength of brick was measured using an automated compressive strength test machine (Eco-Smartz $2000 \mathrm{kN}$ ). Also, the brick was instantaneously immersed in water, from which the change in mass was measured for water absorption capacity. The settings of both tests are illustrated in Figure 1. Each measurement was performed in duplicate, and the average values were reported. 

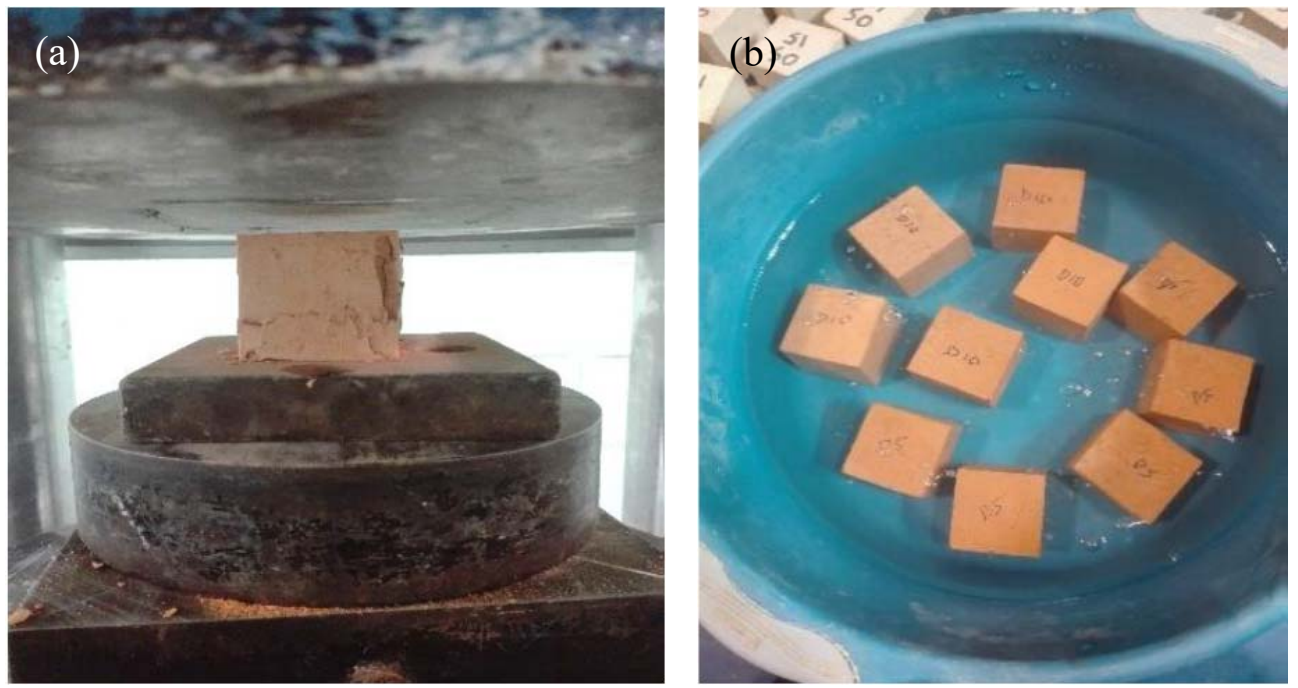

Figure 1. Characterization of bricks: (a) Compressive strength test, (b) water absorption test.

\section{Results and Discussion}

\section{Sludge characteristics}

The oil-rich sludge is composed of $27 \%$ oil, $50 \%$ moisture, and 18 $\%$ ash. The material (dry-ash-free basis) contains $0.325 \%$ nitrogen, $61.8 \%$ carbon, $9.75 \%$ hydrogen, $0.104 \%$ sulfur, and $28 \%$ oxygen. From EDX analysis, the surface composition of ORS consists of $64 \%$ carbon, $23.1 \%$ oxygen and $12.9 \%$ calcium. For ash, its surface contains $42 \%$ calcium, $42 \%$ oxygen, $8.5 \%$ carbon and $6.5 \%$ iron. The oil extract contains mostly fatty acids, with high concentration of silicic acid (ester). ${ }^{11}$ The findings imply that ORS is rich in limestone $\left(\mathrm{CaCO}_{3}\right)$, that could be a promising substitute to iron oxide in brick making.

\section{Compressive strength}

The compressive test is imperative to determine the strength of clay bricks produced. The results of compressive strength of sludge-blended bricks are shown in Figure 2. The values of compressive strength are ranging from $0.85 \mathrm{~N} / \mathrm{mm}^{2}$ to $13.26 \mathrm{~N} / \mathrm{mm}^{2}$. In general, bricks formulated using wet and dry ORS with replacement percentage of lesser than $20 \%$ 
satisfactorily met the minimum strength requirement of $5 \mathrm{~N} / \mathrm{mm}^{2} .^{12}$ It was found that the compressive strength increases as the amount of ORS decreases. The increase in ORS amount results in a less adhesive mixture, in which the porosity volume increases thus decreasing the material strength. The result tied-up with the finding of Liew et al. ${ }^{13}$, wherein the compressive strength decreased with the addition of sludge. Also, a replacement beyond $30 \%$ of sludge is not recommended because the produced brick will be easily ruptured. ${ }^{14}$ The compressive strength of bricks derived from oil-free and ash sludge at replacement of $5 \%$ and $10 \%$ also obeyed the minimum standard of $5 \mathrm{~N} / \mathrm{mm}^{2}$. Nonetheless, the two sludge derivatives are readily porous and show poor compatibility in brick formulation at replacement $>10 \%$.

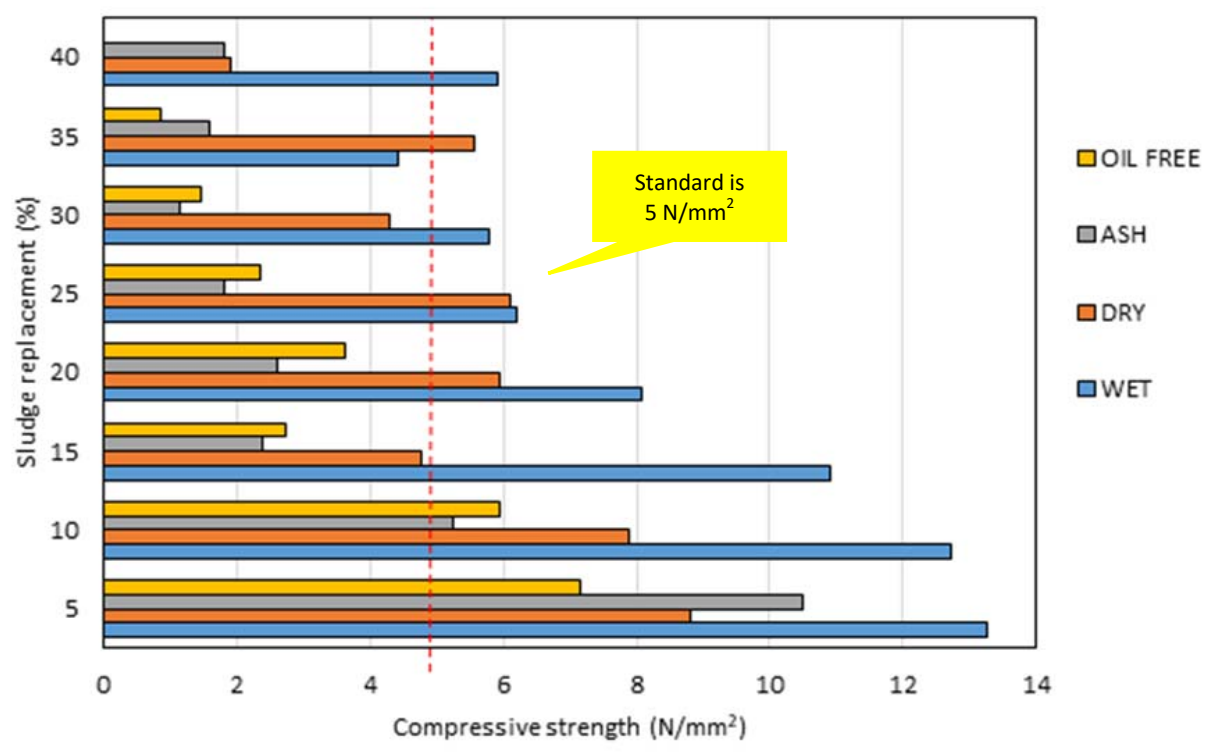

Figure 2. Compressive strength of brick.

\section{Water absorption}

The water absorption test was carried out for sludge-blended clay bricks after firing by measuring the increase in mass. ${ }^{15}$ It reflects the durability and resistance to damage of bricks in weathering. The results are shown in Figure 3, where ash and dry sludge derivatives demonstrate a 
greater water absorption that could be linked to ash (calcium-rich) composition and lack of water (binder) which could result in the development of porous brick matrix. Generally, the water absorption increased with increasing ORS amount in brick. This is associated with the increase porosity of brick because of insufficient binding within the matrix when more ORS was used as replacement. A similar observation was reported by Anyakora ${ }^{16}$. It should be noted that all ORS-incorporated bricks yield high values of water absorption capacity, exceeding the limit for engineering brick of $20 \%$. However, the sludge bricks exhibit general compliance with BS EN 771-1:2003 ${ }^{12}$ for other bricks because of no specific requirement for water absorption as long as the compressive strength is acceptable for general applications. The presence of ORS and the hand-molding method could result in porous brick, hence increasing the water absorption capacity.

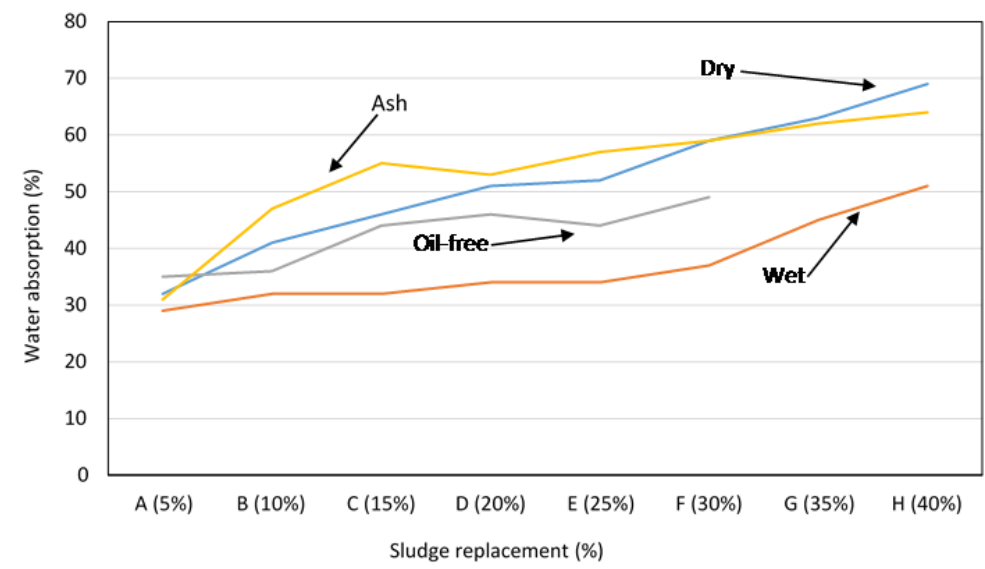

Figure 3. Water absorption of brick.

\section{Firing shrinkage}

Firing shrinkage is the decrease in length (or dimension) of a brick sample after the firing process. As kiln temperature increases some of the 
particles shrink and begin to melt, wherein the bodies densify and pull closer. Firing shrinkage is unavoidable during brick manufacturing at higher temperature. The value of firing shrinkage was determined by dividing the difference in dimension with the actual length, expressed in percentage. ${ }^{5}$ Normally, a standard brick exhibits a firing shrinkage of lower than $8 \%{ }^{17}$ In this work, over $60 \%$ of the sludge bricks formulated displayed the firing shrinkage $<8 \%$ as depicted in Figure 4, obeyed the limit of standard brick. According to Alleman ${ }^{18}$, the acceptable limit of firing shrinkage is between $6 \%$ and $8 \%$.

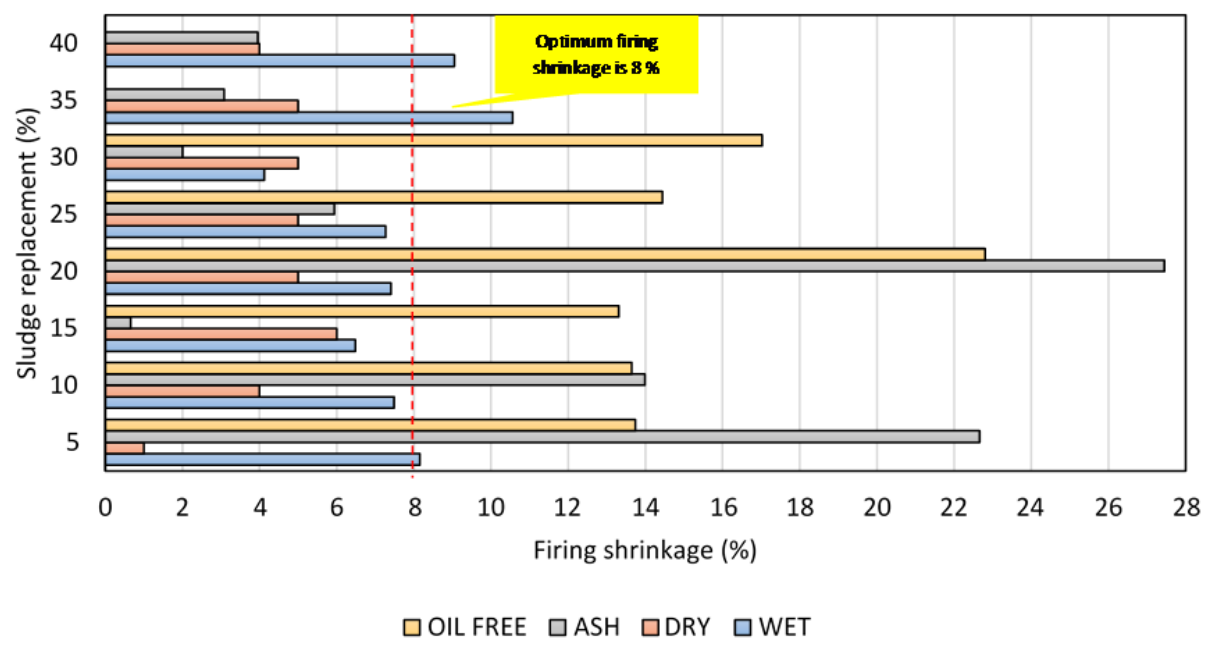

Figure 4. Firing shrinkage of brick.

\section{Brick physical appearance}

The blend of ORS in brick has resulted in the formation of white salt deposits, known as efflorescence, as depicted in Figure 5. The higher the ORS amount, the higher the degree of efflorescence on the surface of brick. It is more prevalent, particularly for sludge replacement $>25 \%$. A hygroscopic salt such as $\mathrm{CaCl}_{2}$ absorbs moisture from the surrounding that brings dampness and efflorescence in brick. A somewhat whitish brick as 
opposed to the standard reddish brick is expected when using foreign sludge as clay substitute to some extent, yet the aesthetic appearance has not completely jeopardized the standard strength of brick as the construction material.
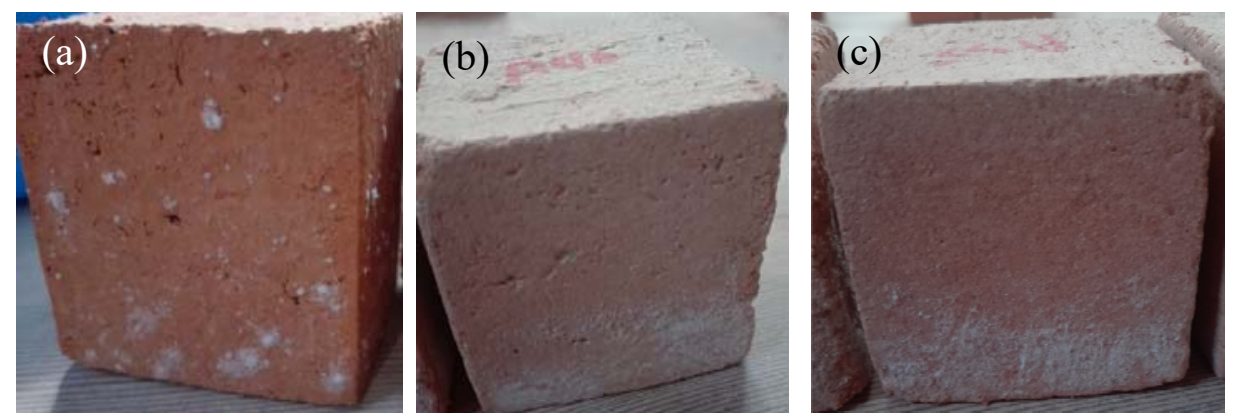

Figure 5. Efflorescence of ORS-blended brick (a) $30 \%$, (b) $40 \%$, (c) $45 \%$.

ORS-formulated sludge is prone to create minor surface crack, while in some conditions, the brick bloats and displays an increase in size. These are visualized in Figures 6. The cracking can be resulted from the conversion of $\mathrm{CaO}$ to $\mathrm{Ca}(\mathrm{OH})_{2}$ during the contact of dry products with surrounding atmosphere or moist conditions. The issues associated with cracking and bloating could also due to slow heating and uncontrolled release of gas from organic matter decomposition during the later phase of firing. ${ }^{13}$ Oxidation with sufficient air circulation often yields bricks with red color. At 450 to $650{ }^{\circ} \mathrm{C}$, the release of bound water may prevent air from entering the core of brick. The residual carbon in brick reacts with steam to produce reducing gases such as hydrogen and $\mathrm{CO} .{ }^{10}$ The reducing environment eventually distorts minerals in clay, thus rendering discoloration and bloated bricks. ${ }^{19}$ 

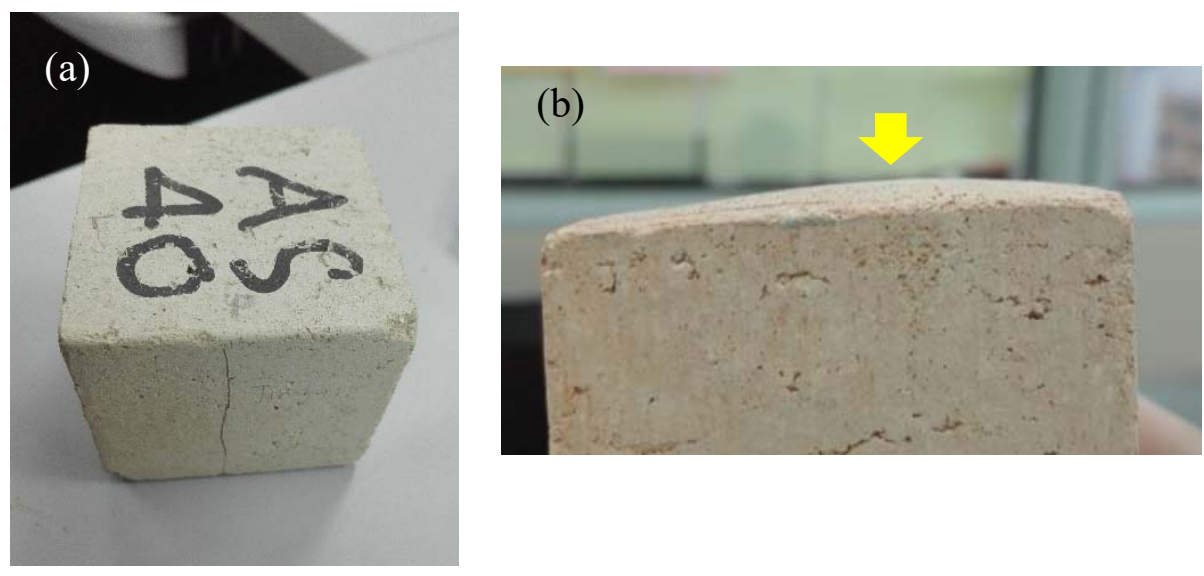

Figure 6. (a) Crack of brick after slow heating, (b) brick bloating.

Figure 7 displays the batch of successful sludge bricks, formulated using wet sludge at replacement of $5 \%$ as compared with the normal clay bricks, both produced at a commercial scale. The surface of sludge bricks is smooth and imparts a light red color probably due to deficient amount of iron oxide. Both batches pass the compressive strength requirement for commercialization.
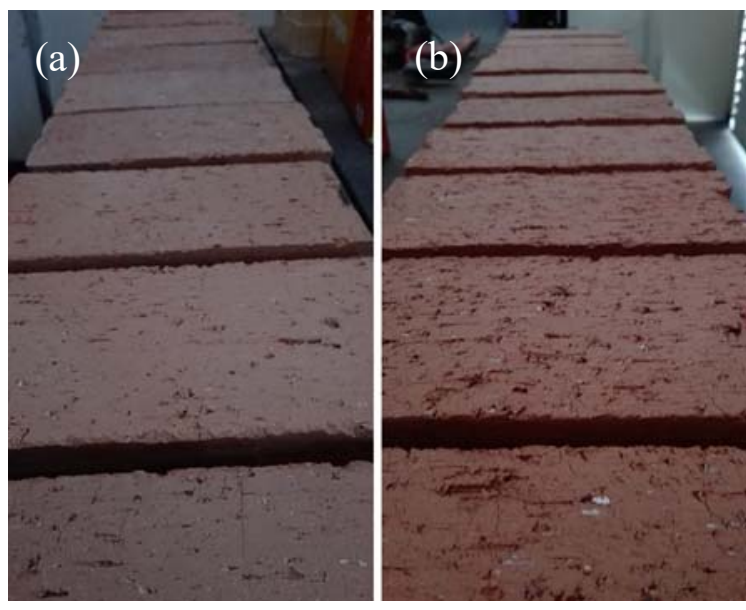

Figure 7. (a) Sludge-blended bricks, (b) normal clay bricks. 


\section{Mechanisms of ORS-clay mixed brick production}

ORS is rich in $\mathrm{CaCO}_{3}$, that holds a similar function as iron oxide in facilitating silica to melt and bind the brick particles together. ${ }^{19}$ The fused silica works as a strong cementing material, enhancing the durability of brick. However, excess $\mathrm{CaCO}_{3}$ in the formulation may cause vitrification of brick due to superfluous fusion of silica. In addition, $\mathrm{CaCO}_{3}$ converts into $\mathrm{CaO}$ during brick firing. Excess $\mathrm{CaO}$ in brick is detrimental because it slakes and expands when contact with water, causing disintegration of brick.

Silica, alumina, iron oxide and lime are the main chemical constituents in clay mixture. Immediate cracking of brick due to large thermal gradient during firing is usually controlled by gradual increase in temperature and slow heating rate. During the course of heating, free water in brick vaporized at $150{ }^{\circ} \mathrm{C}$, organic volatiles released at $300{ }^{\circ} \mathrm{C}$, and clay matter $\left(\mathrm{Al}_{2} \mathrm{O}_{3} \cdot 2 \mathrm{SiO}_{2} \cdot 2 \mathrm{H}_{2} \mathrm{O}\right)$ decomposed into individual elements of silica, alumina and water at $600{ }^{\circ} \mathrm{C}^{10} \mathrm{CaCO}_{3}$ breaks down into $\mathrm{CaO}$ and $\mathrm{CO}_{2}$ at $700{ }^{\circ} \mathrm{C}\left(\mathrm{CaCO}_{3} \rightarrow \mathrm{CaO}+\mathrm{CO}_{2}\right)$. Oxidation at $800{ }^{\circ} \mathrm{C}$ is basically aimed to produce quality bricks by releasing all carbonaceous matter and convert minerals into mineral oxides. Subsequently, vitrification at $900{ }^{\circ} \mathrm{C}$ developed the strength of brick by sintering of clay particles to form new crystalline phases. The solid particles are covered with liquid which upon cooling solidifies as glass that binds the particles together. ${ }^{19}$

\section{Conclusions}

Oil-rich sludge was used in brick manufacture and has shown a promising future for construction sector. The feasible sludge replacement is between $5 \%$ and $20 \%$, renders bricks that surpass the minimum compressive strength of $5 \mathrm{~N} / \mathrm{mm}^{2}$. Also, it is recommended to use only dry 
and wet sludge because the other derivatives of oil-free and ash produce inferior quality of bricks, and further the additional process of drying/heating may as well increase the energy consumption, hence is not environmentally friendly. The increase of sludge amount in clay formulation increases the water absorption capacity and decreases the compressive strength of brick. Moreover, the brick with high sludge content is very brittle. An attempt to mass-produced sludge bricks (5\% blend) at a commercial scale was successful and displayed comparable attributes with normal production of clay bricks. A higher percentage of sludge of up to $20 \%$ in brick is sought towards sustainable development.

\section{Acknowledgements}

We gratefully acknowledged the financial aids under UTM-contract research Nos. 4C141 and $01 \mathrm{M} 57$.

\section{References}

1. Fauziah, S.; Agamuthu, P. Challenges and issues in moving towards sustainable landfilling in a transitory country - Malaysia. Waste Manage. Res. 2010, 29, 13-19.

2. Indah Water Konsortium Sdn Bhd. A Potty History of Sewage Sludge and Treatment, Indah Water Konsortium Sdn Bhd., 2010.

3. Department of Environment. Malaysia Environmental Quality Report, Ministry of Science, Technology and Environment Malaysia, 2002.

4. Jewaratnam, J. Waste recovery from industrial sludges. Engineering eTransaction 2006, 1, 5-8.

5. Kadir, A. A.; Zulkifly, S. N.; Abdullah, M. M.; Sarani, N. A. The utilization of coconut fibre into fired clay brick. Key Eng. Mater. 2016, 673, 213-222.

6. Algamal, Y.; Khalil, N. M.; Saleem, Q. M. Usage of the sludge from water treatment plant in brick-making industry. J. Chem. Technol. Metall. 2018, 53, 504-510.

7. Kadir, A.A.; Salim, N.S.A.; Abdullah, M.M.A-B.; Nawi, M.N.M.; Sandu, A.V. Properties impact from wastewater treatment sludge 
utilized into fired clay bricks. Malaysian Constr. Res. J. 2017, 2, 130142.

8. Eliche-Quesada, D.; Corpas-Iglesias, F. A.; Pérez-Villarejo, L.; IglesiasGodino, F. J. Recycling of sawdust, spent earth from oil filtration, compost and marble residues for brick manufacturing. Constr. Build Mater. 2012, 34, 275-284.

9. Eliche-Quesada, D.; Cunha, R. A-D; Corpas-Iglesias, F. A. Effect of sludge from oil refining industry or sludge from pomace oil extraction industry addition to clay ceramics. Appl. Clay Sci. 2015, 114, 202-211.

10. Toledo, R.; dos-Santos, D. R.; Faria Jr., R. T.; Carrio, J. G.; Auler, L. T.; Vargas, H. Gas release during clay firing and evolution of ceramic properties. Appl. Clay Sci. 2004, 27, 151-157.

11. Fauzi, A. A.; Arsad, A.; Zaini, M. A. A.; Yunus, M. A. M. Extraction of oil from filter cake sludge using soxhlet extraction. J. Eng. Appl. Sci. 2016, 11, 2561-2565.

12. British Standard. British standard specification of clay bricks. BS EN 771-1:2003, 2003.

13. Liew, A.G.; Idris, A.; Samad, A.A.; Wong, C.H.; Jaafar, M.S.; Baki, A.M. Reusability of sewage sludge in clay bricks. J. Mater. Cycles Waste Manag. 2004, 6, 41-47.

14. Liew, A.G.; Idris, A.; Wong, C.H.; Samad, A.A.; Noor, M.J.; Baki, A.M. Incorporation of sewage sludge in clay brick and its characterization. Waste Manage. Res. 2004, 22, 226-233.

15. Zhang, S.P.; Zong, L. Evaluation of relationship between water absorption and durability of concrete materials. Adv. Mater. Sci. Eng. 2014, 1-8.

16. Anyakora, N.V. Characterization and performance evaluation of water works sludge as brick materials. Int. J. Eng. Appl. Sci. 2013, 3, 69-79.

17. Weng, C. H.; Lin, D. F.; Chiang, P. C. Utilization of sludge as brick materials. Adv. Environ. Res. 2003, 7, 679-685.

18. Alleman, J. E. Beneficial use of Sludge in Building Components. Final Report to the National Science Foundation, Program for Civil and Environmental Engineering, Grant No. ISP-8021357, West Lafayette, IN, 1983.

19. Akinshipe, O.; Kornelius, G. Chemical and thermodynamic processes in clay brick firing technologies and associated atmospheric emissions metrics - A review. Journal of Pollution Effects and Control 2017, 5, 112. 